\title{
Perancangan Jaringan Komputer Untuk Sekolah Dasar Dengan Sistem Manajemen Bandwidth Hierarchical Token Bucket
}

\section{Computer Network Design For Elementary School With Bandwidth Hierarchical Management System Token Bucket}

\author{
Jesika Marsaulina Simbolon ${ }^{1}$, Hani Harafani ${ }^{2}$ Rachmawati Darma Astuti $^{3}$ \\ ${ }^{1,3}$ Universitas Bina Sarana Informatika \\ ${ }^{2}$ STMIK Nusa Mandiri \\ jesikasimbolon9@gmail.com ${ }^{1 *}$, hani.hhf@ nusamandiri.ac.id², rachmawati.rcd@bsi.ac.id ${ }^{3}$
}

\begin{abstract}
Abstrak Pada perkembangan teknologi layanan internet menjadi kebutuhan utama sebagai sarana komunikasi dan bertukar informasi. Terutama pada bidang pendidikan seperi sekolah dasar sangat diperlukan fasilitas internet yang penggunanya adalah staff administrasi, guru, siswa melalui internet dapat mengakses berbagai ilmu pengetahuan yang dibutuhkan dengan cepat, sehingga dapat mempermudah proses belajar. Dari sekian banyak pengguna internet layanan internet menjadi buruk. Maka dari itu sistem pembagian bandwidth atau bisa disebut dengan manajemen bandwidth haruslah sesuai dengan kondisi layanan jaringan yang akan diterapkan dan manajemen bandwidth menjadi hal yang sangat diperlukan bagi jaringan multi layanan, karena semakin banyak dan bervariasinya aplikasi yang dapat dilayani oleh suatu jaringan berpengaruh pada penggunaan link dalam jaringan tersebut. Metode dalam penelitian ini menggunakan studi pustaka (library research) dan pengimplementasian menggunakan metode Heararchical Token Bucket yaitu sebuah aplikasi yang berfungsi untuk mengatur pembagian bandwidth. Tujuan analisis ini untuk memberikan adanya sistem management bandwidth menjadikan pembagian secara adil bagi pengguna yang terhubung ke jaringan. Hasil penelitian menunjukkan bahwa metode Hierarchical Token Bucket dapat mengatur streaming dan browsing. Berdasarkan analisis penelitian yang telah dilakukan didapatkan kesimpulan yaitu pengimpelemntasian metode HTB (Hierarchical Token Bucket) untuk manajemen bandwidth telah sesuai dengan kebutuhan dan standar dalam penggunaan internet untuk kegiatan download, upload, streaming dan browsing.
\end{abstract}

Kata Kunci: Bandwidth, HTB, Perancangan, Jaringan, Komputer.

\begin{abstract}
In the development of internet service technology, it has become a major requirement as a means of communication and exchanging information. Especially in the field of education such as elementary schols, internet facilities are very much needed where the users are administrative staff, teachers, students via the internet can access various knowledge needed quickly, so that it can simplify the learning process. Therefore, the bandwidth sharing system or it can be called bandwidth management must be in accordance with the conditions of the network service to be applied and bandwidth management is indispensable for multi-service networks, because the more and more varied applications that can be served by a network have an effect on link usage. In the network. The method in this research uses library research and the implementation uses the Hierarchical Token Bucket method, which is an application that function to regulate the distribution of bandwidth. The purpose of this analysis is to provide a bandwidth management system to make a fair distribution for users connected to the network. The results showed that the Hierarchicak Token Bucket method can regulate bandwidth usage for each client when downloading, uploading, streaming and browsing.
\end{abstract}

Keywords: Bandwidth, HTB, Design, Network, Computer.

Jurnal Bumigora Information Technology (BITe)

Vol.3, No.1, Juni 2021, pp. 56-68

ISSN: 2685-4066

DOI: 10.30812/bite.v3i1 


\section{Pendahuluan}

Di Era globalisasi saat ini internet menjadi kebutuhan yang penting untuk menunjang kehidupan sehari-hari dalam mencari berbagai informasi. Terbatasnya Bandwidth yang disebabkan oleh operator internet memaksa para pengguna untuk pintar menggunakan jatah bandwidth yang tersedia. Bandwidth adalah ukuran yang menunjukkan seberapa banyak data yang dapat dilewatkan dalam sebuah network. Besar bandwidth pada jaringan akan mempengaruhi kecepatan jaringan dalam melakukan sebuah proses transfer data ke internet. Keberadaan dan peran teknologi informasi dalam sistem pendidikan telah membawa era baru perkembangan dunia pendidikan, tetapi perkembangan tersebut belum diimbangi dengan sumber daya manusia (SDM) yang menentukan keberhasilan dunia pendidikan di Indonesia pada umumnya [1].

Teknologi juga semakin berkembang seiring dengan manusia yang menginginkan kemudahan, kecepatan dan keakuratan dalam memperoleh informasi. Media yang digunakan untuk menyampaikan informasi pun bervariasi baik media cetak maupun media elektronik. Salah satu media elektronik yang paling cepat dalam menyampaikan informasi adalah melalui jaringan internet, karena penggunaan jaringan internet yang semakin pesat.

Pada perkembangan teknologi saat ini, layanan internet menjadi kebutuhan utama sebagai sarana komunikasi dan bertukar informasi. Selain itu banyak aspek kehidupan yang bisa dilakukan dengan layanan internet. Terutama pada bidang pendidikan seperti sekolah dasar sangat diperlukan fasilitas internet yang digunakan oleh staff administrasi, guru, dan siswa melalui internet dapat mengakses berbagai ilmu pengetahuan yang dibutuhkan dengan cepat, sehingga dapat mempermudah proses belajar. Dari sekian banyak pengguna internet dan kebutuhan bandwidth yang semakin meningkat, menimbulkan kecepatan layanan internet menjadi buruk [2]. Wisesa dkk mengatakan penggunaan bandwidth pada setiap pengguna tidak beraturan menyebabkan beberpa pengguna tidak dapat menggunakan bandwidth secara merata. Sehingga banyak terjadi pengguna internet yang menggunakan data lebih banyak dibandingkan pada pengguna yang lain [3]. Maka dari itu sistem pembagian bandwidth atau biasa disebut dengan manajemen bandwidth haruslah sesuai dengan kondisi layanan jaringan yang akan diterapkan. HTB merupakan teknik yang menggunakan Classful Queueing Disciplines yang memperbolehkan paket diarahkan ke class tertentu dan antrian subqueues [4], [5].

Pada saat ini sudah ada beberapa penelitian yang sudah dilakukan mengenai manajemen bandwidth, penelitian yang dilakukan oleh Sari dan Sukri dengan judul analisis penerapan metode antrian Hierarchical Token Bucket untuk Management Bandwidth jaringan internet. Menggunakan metode manajemen bandwidth HTB untuk menganalisis implementasi penggunaan bandwidth pada setiap client [6]. Yang dinilai efektif untuk membagi bandwidth secara adil dan merata kepada masing-masing client. Penelitian sejenis yang dilakukan oleh [7] dengan judul penerapan quality of service pada jaringan internet menggunakan metode hierarchical token bucket yang mengimplementasikan metode HTB pada suatu jaringan internet dengan QoS untuk menjamin hasil dari digunakannya metode tersebut. Selain itu, penelitian terkait dilakukan oleh Hairani dan Mardedi[4], dengan penelitian Analisa penerapan Hierarchical Tokken Buket untuk optimalisasi management bandwith pada server Ubuntu. Hasil dari penelitian tersbut yaitu Pada pengujian speedtest sebelum di aktifkan HTB untuk unduh di dapatkan kecepatan 11,32 Mbps sedangkan untuk unggah 10,93 Mbps, untuk streaming Youtube 6,992 Mbps. Setelah diaktifkan HTB maka pengujian speedtest untuk unduh 1,1 Mbps sedangkan untuk unggah 1,63 Mbps, untuk streaming Youtube 1,025 Mbps.

Berdasarkan uraian diatas, maka dibuatlah sebuah penelitian yang berjudul "Perancangan Jaringan Komputer Untuk Sekolah Dasar Dengan Sistem Management Herarchical Token Bucket (HTB)". Tujuan dari penelitian ini adalah mengatur jumlah bandwidth agar sesuai dengan kebutuhan penggunaan internet untuk kegiatan download, upload, streaming dan browsing bagi setiap user tanpa membuat salah satu user mendominasi penggunaan bandwidth pada jaringan internet. Membagi bandwidth secara adil bagi pengguna yang terhubung kedalam jaringan komputer.

https://journal.universitasbumigora.ac.id/index.php/bite ISSN: 2685-4066 


\section{Metode Penelitian}

\subsection{Analisa Kebutuhan Jaringan}

Analisa kebutuhan jaringan yang akan digunakan dalam memecahkan masalah untuk mencapai tujuan penelitian. pada Ruang Guru menggunakan bandwidth sebesar 50Mbps dan ruang kepala sekolah/ruang tata usaha menggunakan bandwidth sebesar 20Mbps. Pada bagian ini, dijelaskan analisa kebutuhan jaringan yang akan digunakan dalam memecahkan masalah untuk mencapai tujuan penlitian. Setelah manajemen bandwidth diterapkan maka dilakukan analisis kecepatan download, streaming dan browsing dengan menggunakan software netbalancer, internet download manager, eagle dan nperf.com. hal ini dilakukan untuk melihat kecepatan transfer data pada saat downstream setelah adanya penerapan sistem manajemen bandwidth. Hasil dari analisa jaringan di Sekolah Dasar menurut penulis dari sistem jaringan sudah baik tetapi masih ada kekurangan dari sistem manajemen bandwidth dibutuhkannya perangkat software dan jaringan ISP.

Tabel 1. Perangkat Keras

\begin{tabular}{|c|c|}
\hline Perangkat & Spesifikasi \\
\hline \multirow{8}{*}{$\begin{array}{l}\text { Mikrotik } \\
\text { CCR1016 }\end{array}$} & CPU : Tilera Tile-Gx36 1,2Ghz 36 Cores \\
\hline & RAM : 4GB Sodim \\
\hline & LAN Ports : 12 \\
\hline & Gigabit : Yes \\
\hline & USB : 1 \\
\hline & Power Jack : 110/220v \\
\hline & Dimentions : $1 \mathrm{U}$ case: $355 \times 145 \times 55 \mathrm{~mm}$ \\
\hline & Operating System : RouterOSv6 \\
\hline Switch & D-LINK \\
\hline \multicolumn{2}{|l|}{ Konektor } \\
\hline \multirow{6}{*}{$\begin{array}{c}\text { Access } \\
\text { Point } \\
\text { Mikrotik } \\
\text { Rb } \\
\text { cAp2nd }\end{array}$} & CPU : QCA9533 650MHz \\
\hline & RAM : 64MB \\
\hline & LAN Ports : 1 \\
\hline & USB : 0 \\
\hline & Dimentions : 185 x $31 \mathrm{~mm}$ \\
\hline & Operating System : RouterOS \\
\hline \multirow{3}{*}{$\mathrm{PC}$} & Intel ${ }^{\circledR}$ Core $^{\mathrm{TM}} \mathrm{i} 3-6006 \mathrm{U}$ \\
\hline & 4 Gb DDR4 \\
\hline & 1 Tera $5400 \mathrm{rpm}$ \\
\hline
\end{tabular}

https://journal.universitasbumigora.ac.id/index.php/bite

ISSN: 2685-4066 


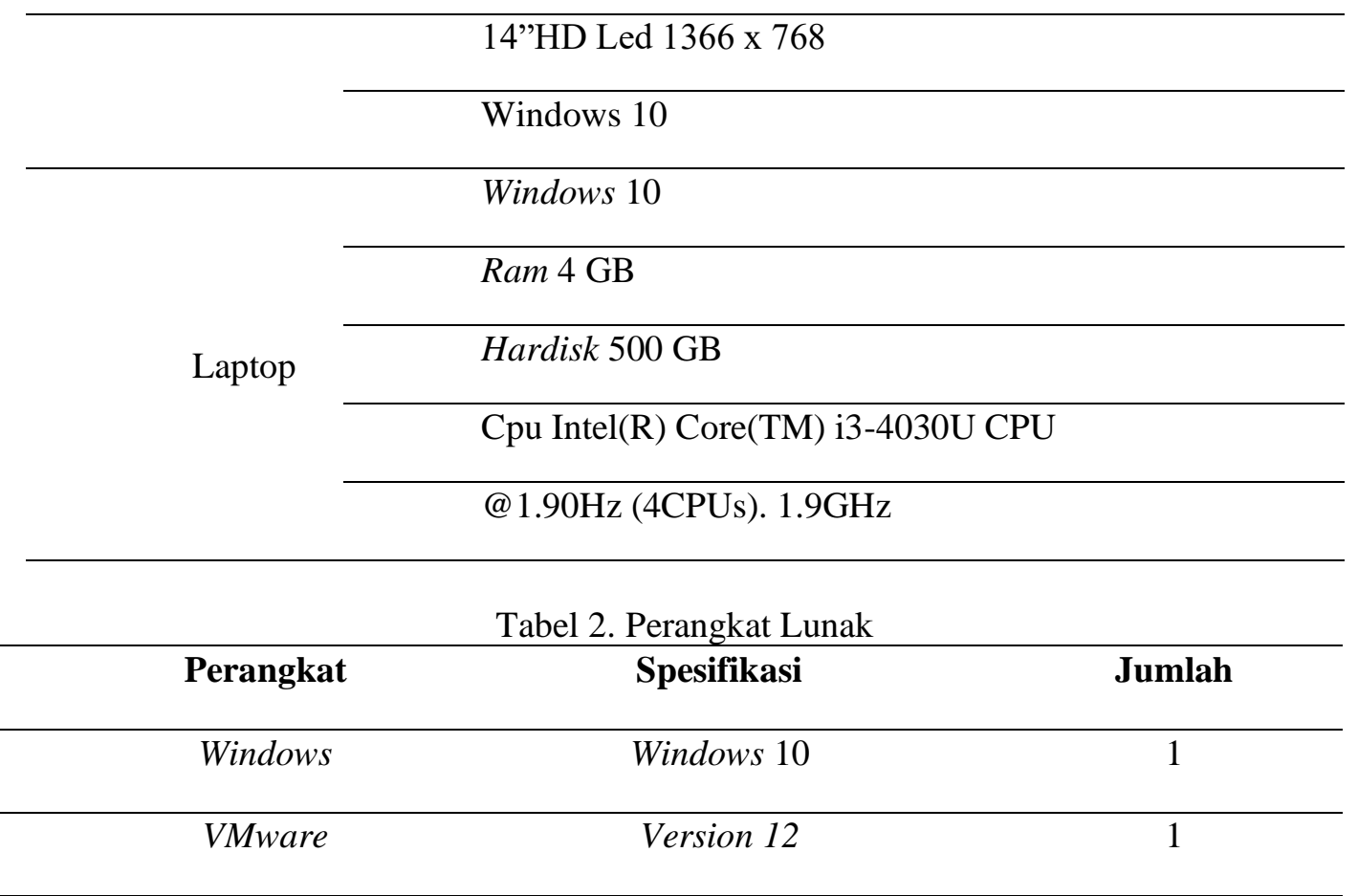

kebutuhan sistem jaringan yang akan dilakukan adalah desain Hierarchical Token Bucket (HTB) dan kemudian menerapkan manajemen bandwidthdengan metode Hierarchical Token Bucket (HTB). Hierarchical Token Bucket (HTB) adalah metode pengelompokkan queue atau antrian yang berguna untuk menangani berbagai jenis trafik [8]. Hierarchical Token Bucket (HTB) berfungsi untuk mengatur pembagian Bandwidth, pembagian dilakukan secara hirarki yang dibagi-bagi kedalam ruangan sehingga mempermudah pengaturan bandwidth dengan tepat sehingga penggunaannya menjadi maksimal[9][10].

Hierarchical Token Bucket (HTB) dianalisis untuk dilihat kecepatan pada saat download dan streaming sesuai dengan yang ditetapkan yaitu kecepatan download minimal adalah $256 \mathrm{Kbps}$ dan kecepatan download maksimal 8 Mbps. Sedangkan kecepatan browsing dilihat keseuaiannya dengan standar SETDA (The State Educational Technology Directory Association). Standar SETDA ditunjukan pada tabel berikut:

Tabel 3. Bandwith Standar

\begin{tabular}{lc}
\hline \multicolumn{1}{c}{ AKTIVITAS } & $\begin{array}{c}\text { REKOMENDASI } \\
\text { BANDWIDTH }\end{array}$ \\
\hline Email dan Web Browsing & $500 \mathrm{Kbps}$ \\
\hline Download 1Mb E-book dalam 5-3 Detik & $1.5 \mathrm{Mbps}$ \\
\hline Pembelajaran Online & $250 \mathrm{Kbps}$ \\
\hline Streaming HD Video & $4 \mathrm{Mbps}$ \\
\hline Skype Video Group (7-10) Orang & $8 \mathrm{Mbps}$ \\
\hline Download Film 6144 Mb dalam 8 Menit & $100 \mathrm{Mbps}$ \\
\hline
\end{tabular}

https://journal.universitasbumigora.ac.id/index.php/bite

ISSN: 2685-4066 
Blok jaringan adalah gambaran jaringan komputer yang ada pada instansi sekolah.

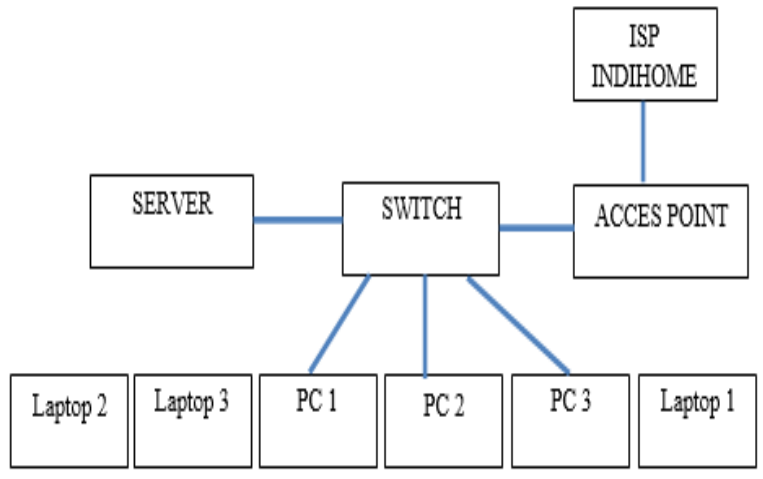

Gambar 1. Blok Jaringan

Blok jaringan yang terdapat pada gambar diatas merupakan blok jaringan Local Area Netwwork (LAN) yang ada pada sekolah. Jaringan ini menghubungkan beberapa jaringan yang terdapat pada masing-masing ruangan sekolah.Server utama yang terletak khusus pada ruang server.Pada ruangan selanjutnya terdapat accesspoint di ruang kepala sekolah.

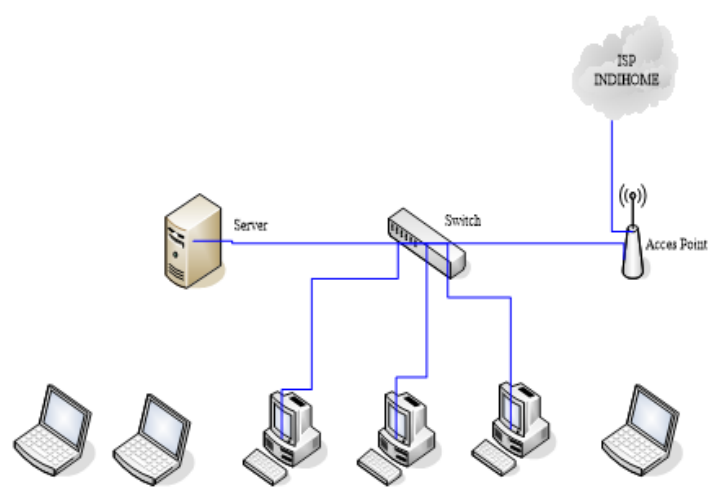

Gambar 2. Skema Jaringan

Pada sekolahan terdapat 1 server dan 3 client yang terhubung ke switch untuk di hubungkan ke internet menggunakan kabel LAN dan terdapat 12 client yang terhubung wifi. Ip address yang digunakan pada jaringan ini adalah static sehingga IP yang digunakan tidak berubah-ubah. IP Address yang terdapat pada server 192.168.1.2 dengan Net id 192.168.1.0, subnet 255.255.255.0.Sedangkan server yang terhubung biasanya digunakan ketika sedang menginput nilai raport siswa.ISP yang digunakan pada jaringan di sekolah menggunakan INDIHOME. 


\begin{tabular}{|c|c|c|c|}
\hline \multicolumn{4}{|c|}{ Tabel 4. IP Address } \\
\hline No & $\begin{array}{c}\text { Perangkat } \\
\text { Keras }\end{array}$ & IP Address & Subnet \\
\hline \multicolumn{4}{|l|}{ Sekolah } \\
\hline 1 & $\begin{array}{l}\text { Modem } \\
\text { (Indihome) }\end{array}$ & 192.168.1.1 & 255.255 .255 .0 \\
\hline 2 & Server & 192.168.1.2 & 255.255 .255 .0 \\
\hline \multirow{3}{*}{3} & \multirow{3}{*}{$\begin{array}{l}\text { PC Client } \\
\text { (3 Client) }\end{array}$} & 192.168.10.2 & 255.255 .255 .0 \\
\hline & & 192.168.10.3 & 255.255 .255 .0 \\
\hline & & 192.168.10.4 & 255.255 .255 .0 \\
\hline \multirow{3}{*}{4} & \multirow{3}{*}{$\begin{array}{l}\text { Laptop } \\
\text { Client (3 } \\
\text { Client) }\end{array}$} & 192.168 .10 .5 & 255.255 .255 .0 \\
\hline & & 192.168 .10 .6 & 255.255 .255 .0 \\
\hline & & 192.168 .10 .7 & 255.255 .255 .0 \\
\hline
\end{tabular}

Sistem keamanan jaringan bandwidth maupun komputer menggunakan model atau metode keamanan jaringan pada komputer server maupun komputer client yaitu menggunakan firewall bawaaan windows dan antivirus smadav, untuk lebih jelasnya Keamanan jaringan yang digunakan pada sekolah sebagai berikut yaitu:

1. Sistem keamanan jaringan maupun komputer menggunakan model atau metode jaringan pada komputer server maupun komputer client yaitu menggunakan firewall bawaan windows dan antivirus smadav.

2. Penggunaan antivirus Microsoft Essential (defender) dan firewall pada server.

Pada tahap awal dilakukan konfigursai router miktorik. Konfigurasi dilakukan dengan menggunakan mikrotik tipe CCR1016 sehingga tidak memerlukan proses penginstalan. Dalam sistem ini pengakses mengunakan VMWare. Berikut langkahnya:

1. Winbox Mikrotik

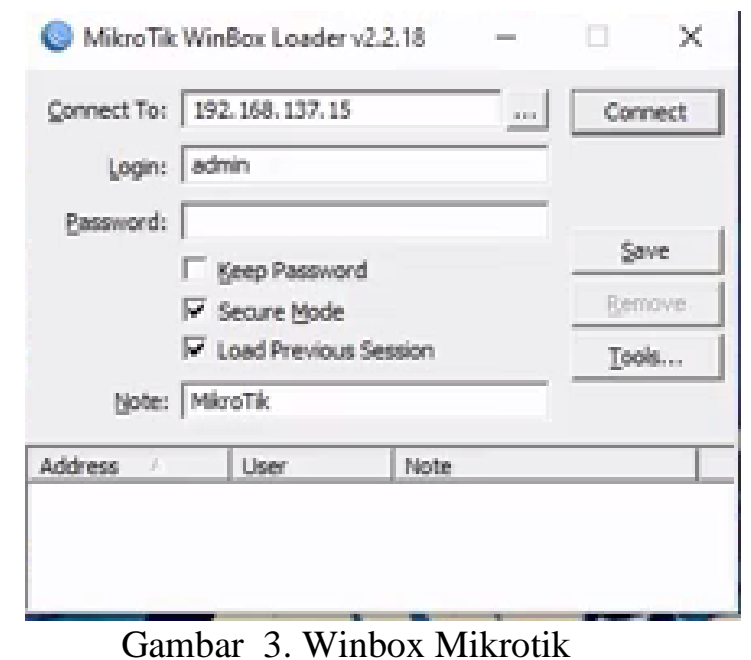

https://journal.universitasbumigora.ac.id/index.php/bite

ISSN: 2685-4066 
2. Setting Router

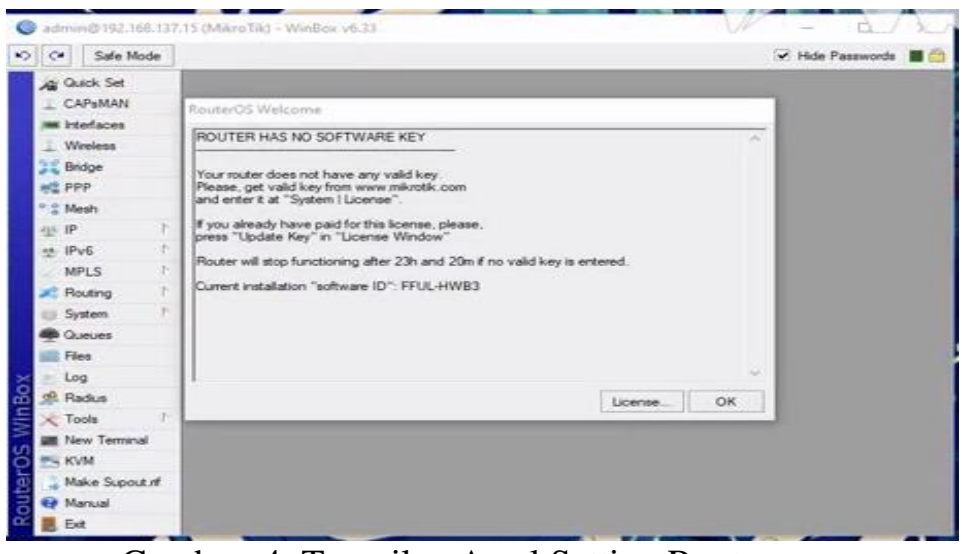

Gambar 4. Tampilan Awal Setting Router

3. Setting IP Address

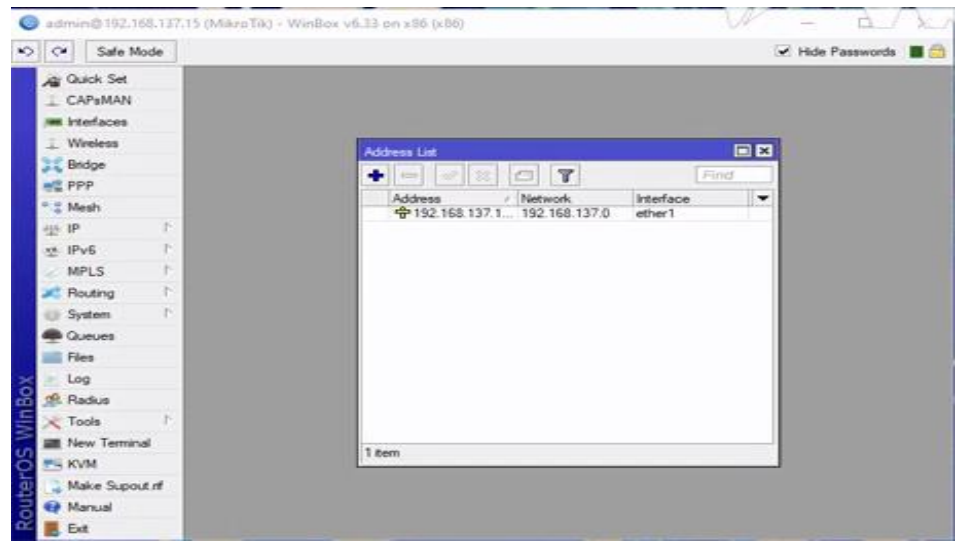

Gambar 5. Setting Ip Address

4. Setting NAT Rule

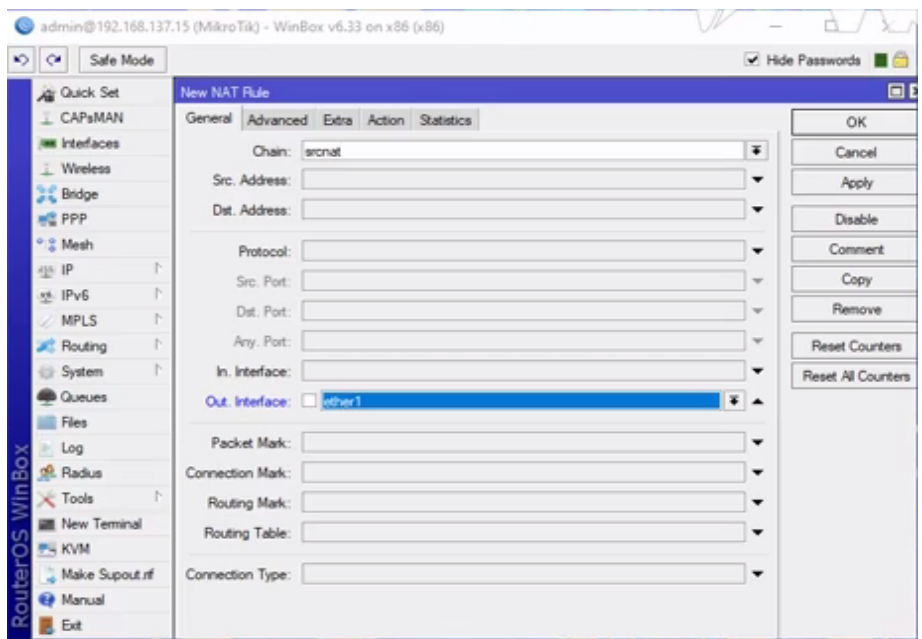

Gambar 6. Setting NAT Rule 
5. Setting DNS Server

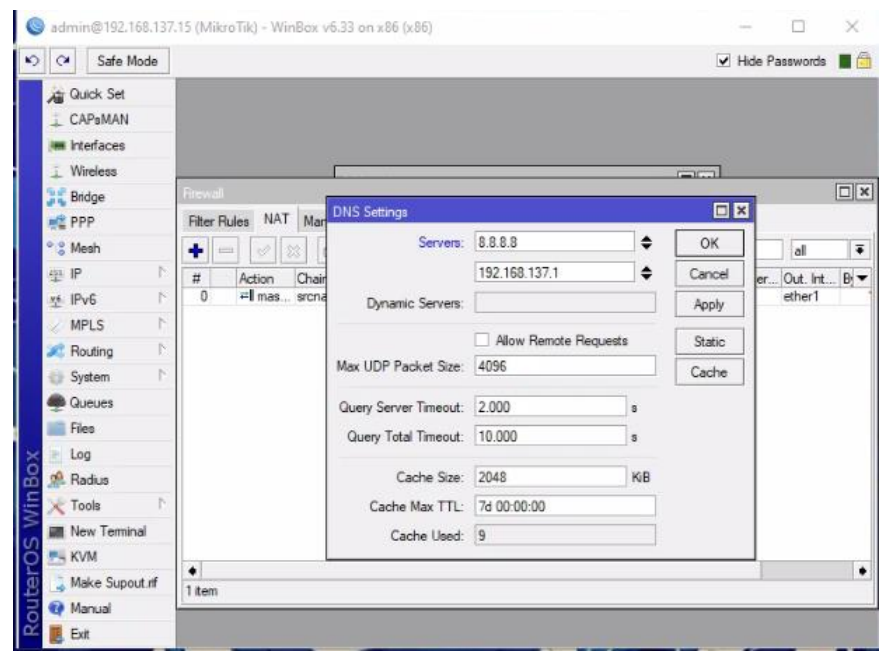

Gambar 7. Tampilan Awal Mikrotik

6. Setting Marge Rule

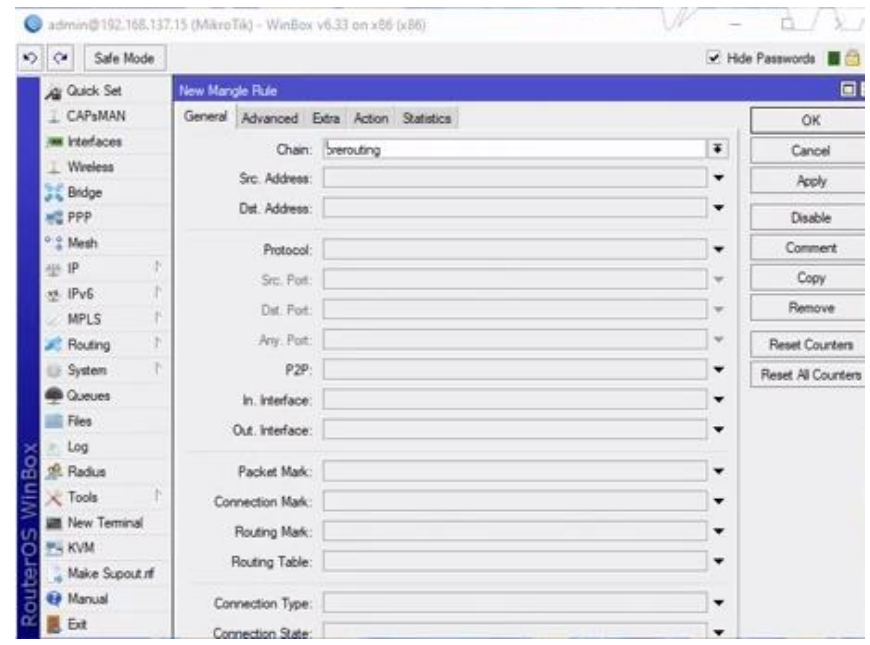

Gambar 8. Konfigurasi Router Mikrotik

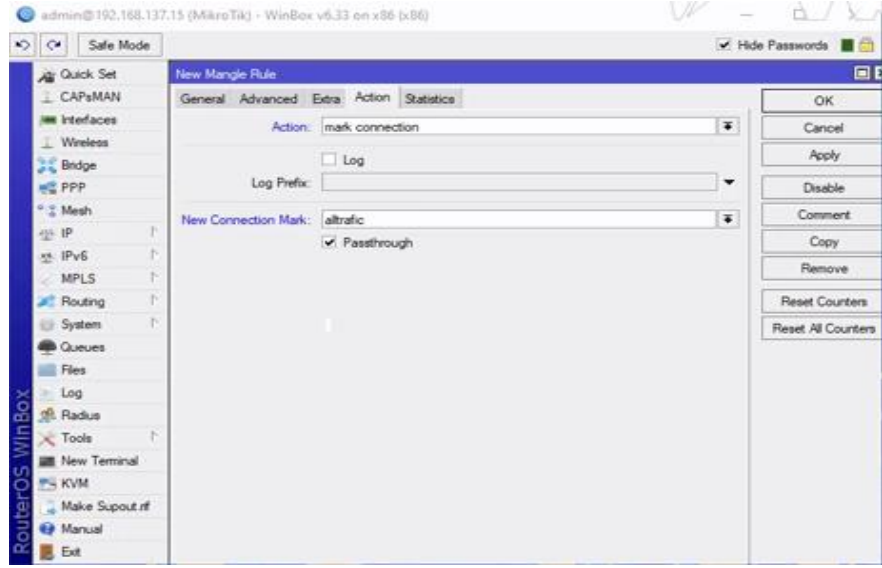

Gambar 9. Correction Mark 


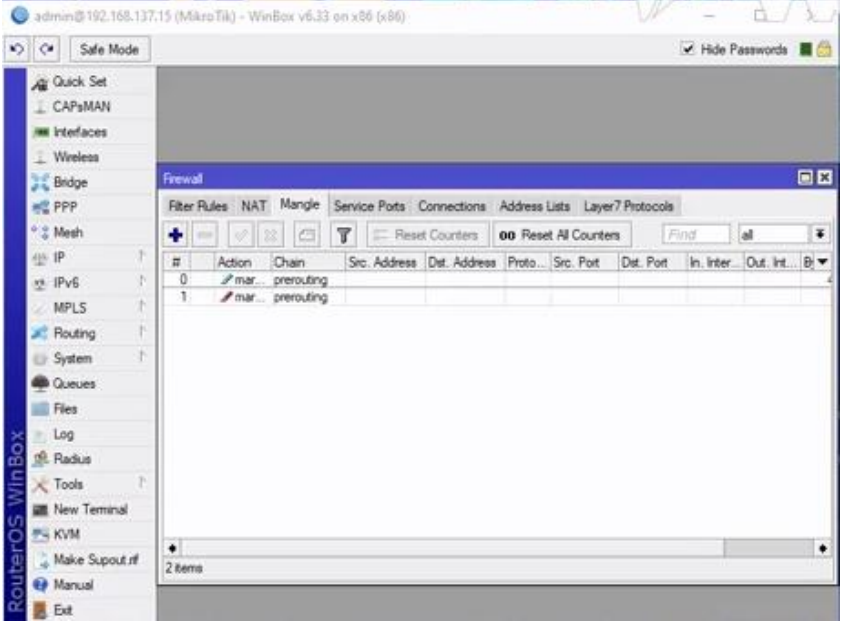

Gambar 10. Hasil Setting Correction Mark

7. Setting Queque

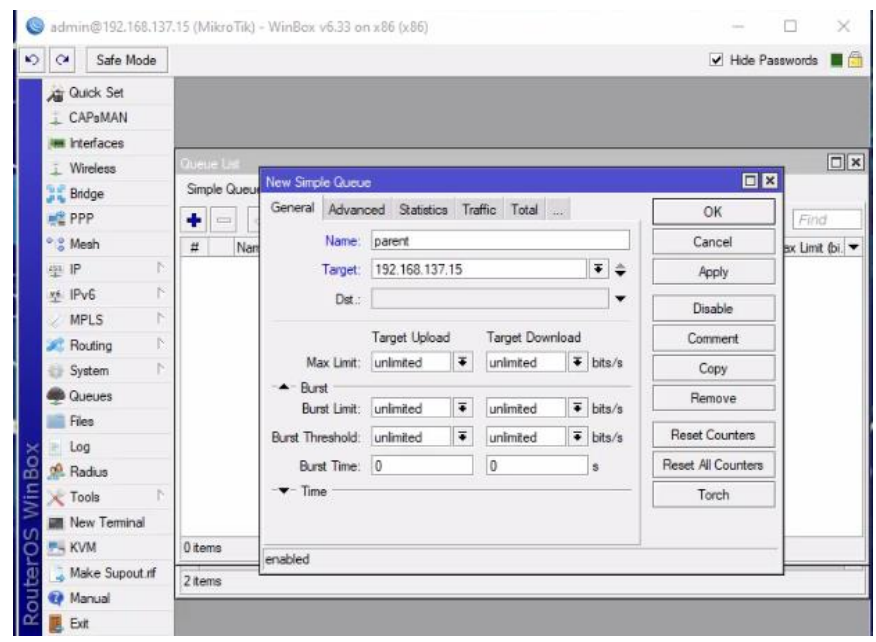

Gambar 11. Konfigurasi Queque

8. Konfigurasi Queque

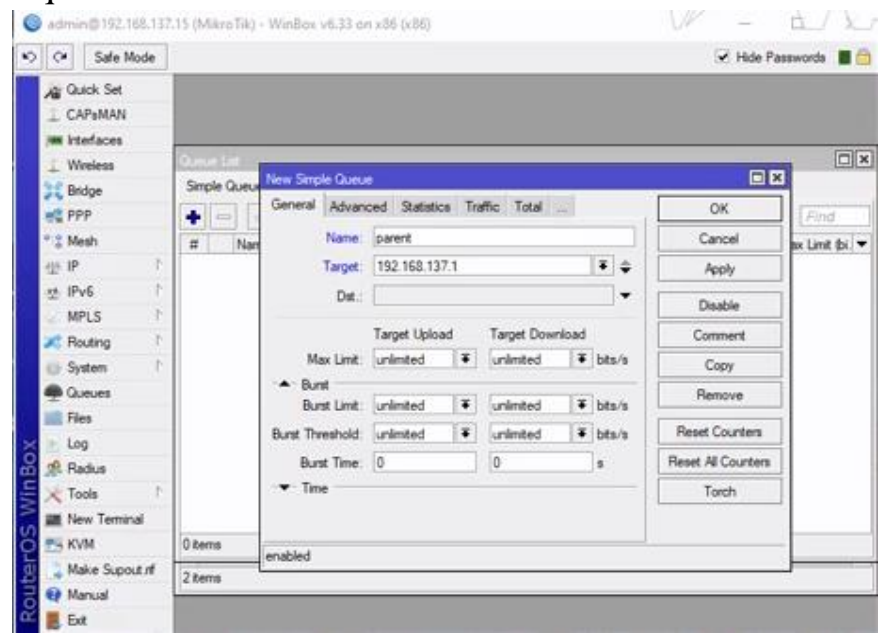

Gambar 12. Konfigurasi Queque

https://journal.universitasbumigora.ac.id/index.php/bite ISSN: 2685-4066 
9. Konfigurasi Queque Client

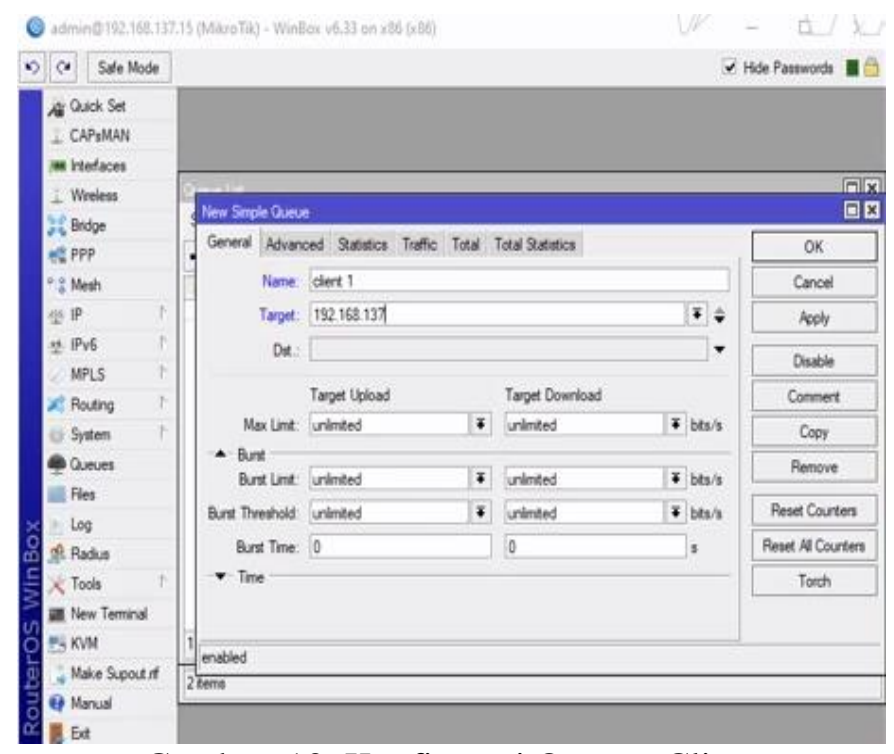

Gambar 13. Konfigurasi Queque Clien

10. Konfigurasi HTB

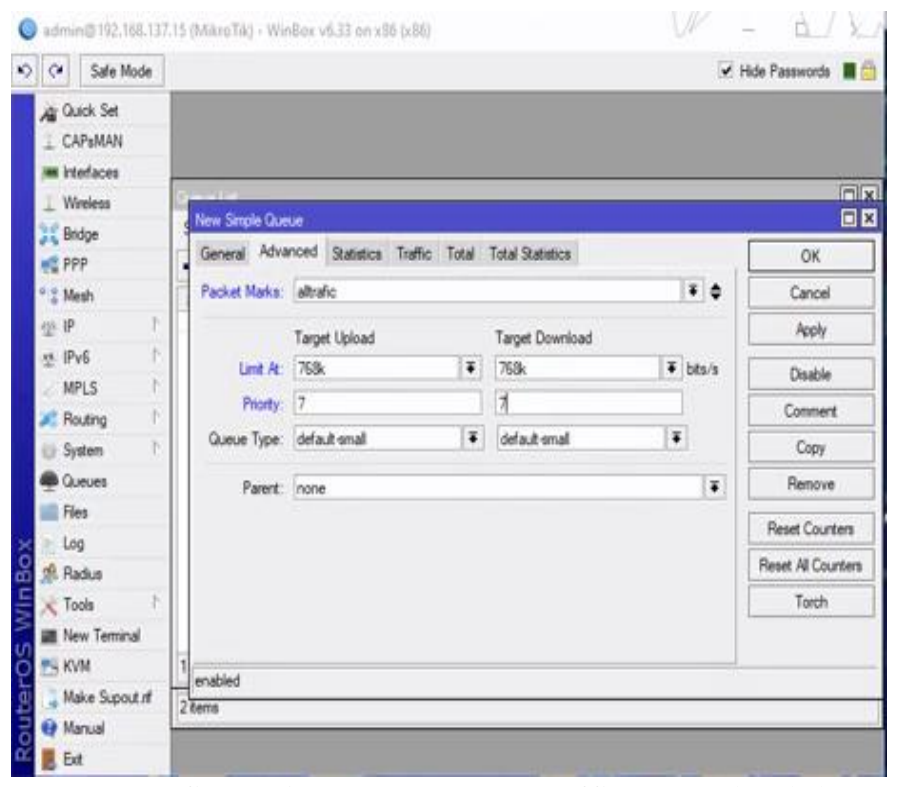

Gambar 14. Konfigurasi Parent Queue Traffic Download dan Upload 


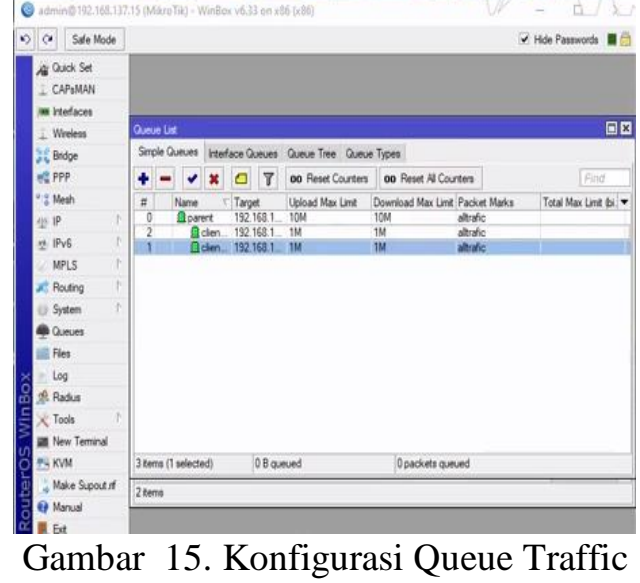

\section{Hasil dan Pembahasan}

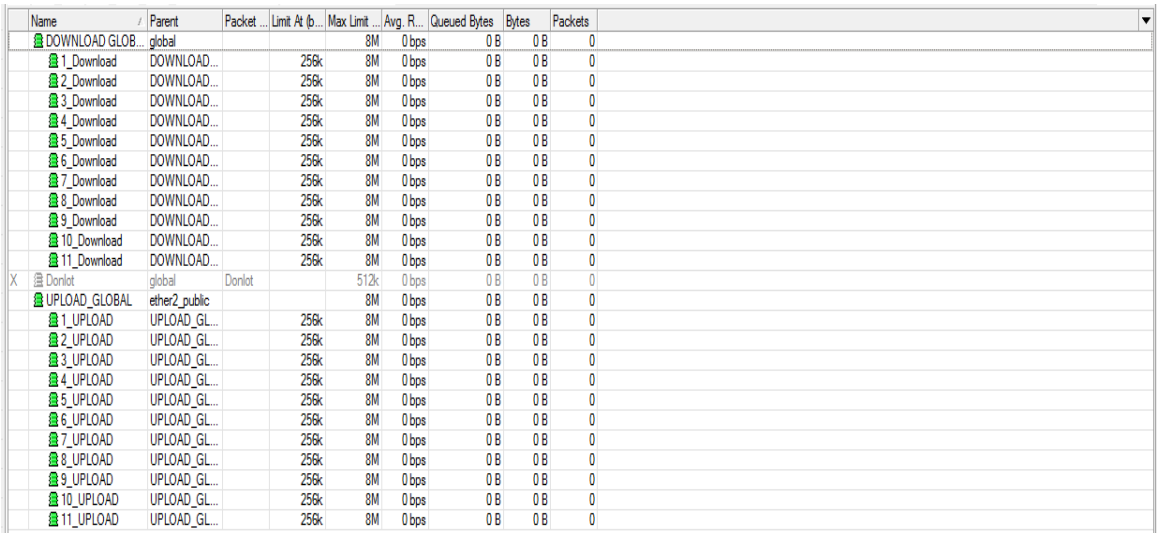

Gambar 16. Hasil Akhir Konfigurasi Dengan Metode HTB

Hasil dari pengimplementasian management bandwidth dengan metode HTB dapat membatasi kegiatan download pada tiap perangkat untuk masing-masing user. Selain itu pengimplementasian metode HTB ini dapat memprioritaskan pembagian bandwidth secara maksimal untuk masing-masing user.
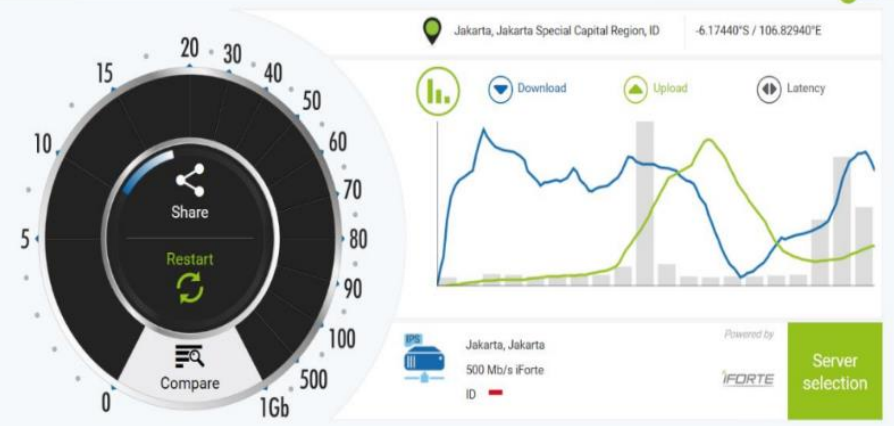

Gambar 17. Pengujian

Hasil pengujian dengan metode HTB ini didapatkan hasil bahwa kecepatan akses download telah sesuai dengan standar 


\begin{abstract}
4. Kesimpulan
Kesimpulan berikut diperoleh berdasarkan analisis penelitian yang telah dilakukan dengan tujuan untuk memperbaharui konfigurasi jaringan pada sekolah maka didapatkan kesimpulan, yaitu pengimplementasian metode HTB untuk manajemen bandwidth telah sesuai dengan kebutuhan dan standar SETDA (The State Educational Technology Directory Association) dalam penggunaan internet untuk kegiatan download, streaming dan browsing. Perancangan topologi jaringan yang sudah sesuai dengan kebutuhan sekolah dasar dalam pengelolaan manajemen bandwidth.
\end{abstract}

\title{
Ucapan Terima Kasih
}

Terimakasih kepada tim Jurnal BITe yang telah memberikan kesempatan untuk menerbitkan jurnal ini.

\section{Referensi}

[1] H. Budiman, "Peran Teknologi Informasi Dan Komunikasi Dalam Pendidikan," Al Tadzkiyyah Jurnal Pendidikan Islam, vol. 8, no. 1, 2017.

[2] J. F. Irianto, "Pengertian dan Jenis-jenis Topologi Jaringan," Jurnal Teknologi Informasi (Ilmuti), 2013.

[3] P. A. Wisesa, Bagas, and Dkk, "Analisa perbandingan sistem manajemen bandwidth berbasis Class-Based Queue dan Hierarchical Token Bucket untuk jaringan Komputer," Universitas Brawijaya, 2018.

[4] R. Haerani and L. Z. A. Mardedi, "Analisa Penerapan Hierarchical Tokken Buket Untuk Optimalisasi Management Bandwith Pada Server Ubuntu," Jurnal Bumigora Information Technology (BITe), vol. 2, no. 2, pp. 139-148, 2020, doi: 10.30812/bite.v2i2.917.

[5] A. M. Lukman and Y. Bachtiar, "Analisis Sistem Pengelolaan, Pemeliharaan dan Keamanan Jaringan Internet Pada IT Telkom Purwokerto," Evolusi : Jurnal Sains dan Manajemen, vol. 6, no. 2, pp. 49-56, 2018, doi: 10.31294/evolusi.v6i2.4427.

[6] I. P. Sari and S. Sukri, "Analisis Penerapan Metode Antrian Hirarchical Token Bucket untuk Management Bandwidth Jaringan Internet," Jurnal RESTI (Rekayasa Sistem dan Teknologi Informasi), vol. 2, no. 2, 2018, doi: 10.29207/resti.v2i2.458.

[7] C. P. Antodi, A. B. Prasetijo, and E. D. Widianto, "Penerapan Quality of Service Pada Jaringan Internet Menggunakan Metode Hierarchical Token Bucket," Jurnal Teknologi dan Sistem Komputer, vol. 5, no. 1, 2017, doi: 10.14710/jtsiskom.5.1.2017.23-28.

[8] I. Riadi, W. P. Wicaksono, P. Studi, S. Informasi, and U. A. Dahlan, "Implementasi Quality of Service M enggunakan Metode Hie rarchical Token Bucket Landasan Teori," JUSI Vol. 1, No. 2 September 2011, vol. 1, no. 2, pp. 93-104, 2011.

[9] P. Dursun, "Implementasi Quality Of Service Dengan Metode HTB (Hieraticle Token Bucket) Pada PT.Komunica Lima Duabelas," Jurnal Elektronik Ilmu Komputer, vol. 66, no. December, pp. 37-39, 2012.

[10] L. Lukman, A. M. Saputro, A. S. Wicaksono, F. H. T. Hartomo, and M. N. Jatun, "Manajemen Bandwidth Menggunakan Metode Hierarchical Token Bucket (HTB) di Farid.net," Creative Information Technology Journal, vol. 5, no. 3, p. 209, 2019, doi: 10.24076/citec.2018v5i3.237. 